\title{
A Man in Crisis or a Crisis of Men? Masculinity and Societal Challenge in the 1970s in Sweden
}

\author{
By \\ Kristofer Hansson
}

\begin{abstract}
'Individual crisis', as a psychological term, was introduced in a Swedish context in the late 1960s. In this article, 'individual crisis' is analysed as a concept in order to understand how masculinity and emotion came to matter in Sweden in the 1970s - not least to bring about gender equality in Swedish welfare society. With 'individual crisis' as the empirical starting point for pinpointing the way men were to create a new identity and how new psychological knowledge circulated in society, it is possible to analyse which masculinity ideals and norms existed at the time. The focus of this article is on self-help and debate books that drove the discussion in the 1970s.
\end{abstract}

Keywords: Individual crisis, hegemonic masculinity, Johan Cullberg, psychological, welfare society, self-help books.

Hansson, Kristofer: "A Man in Crisis or a Crisis of Men? Masculinity and societal challenge in the 1970s in Sweden", Culture Unbound, Volume 12, issue 3, 2020: 550-568. Published by Linköping University Electronic Press: http://www. cultureunbound.ep.liu.se 


\section{Introduction}

The man has been directly linked to working life and its patriarchal patterns. As patriarchy now takes on new forms, so does the role of men (Centerwall, 1978: 82). ${ }^{1}$

With this kind of argumentative perspective, in the 1970s, the prevailing masculinity norms were criticized with a focus on men and emotions. In previous research, men and emotions are said to foster and generate gender equality (de Boise \& Hearn, 2017). However, this discussion of an improvement of men and their masculinity is not new but has rather recurred in different historical phases. One of these periods can be found in the Swedish progressive political climate of the 1970s, when men and emotion became a central topic in the political struggle for a more gender-equal welfare society. Psychological self-help books and debate books at the time addressed the notion that men should take more responsibility for their emotions in order to bring about societal change. It was said that men, and their masculinity, were in crisis, and that men had a responsibility to make a change. Masculinity became a topic in itself. One suggestion was that men should learn to listen to their emotions. This argumentation is especially visible in the psychological concept of 'individual crisis' ${ }^{2}$ that was introduced in Sweden at this time.

As a psychological term, 'individual crisis' was introduced in the Swedish context in the late 1960s (cf. Hansson, 2012 \& 2013). Having a crisis was framed as natural, and also meaningful, to grow psychologically as a human being. The term quickly came to be used in many different contexts. In movies and novels, the term, or similar ones, was used to describe much more broadly the meaning of men in crisis. It was as though the crisis offered the opportunity and freedom to leave an old and solidified family life. It was an 'excuse' to find a new, more fulfilling 'Self'. In this way, the term 'crisis' seemed to circulate in society and be used on various occasions.

Parallel to this development, a societal challenge also seemed to arise when it was debated that men should be more engaged in household chores and childcare (cf. Eduards, 2002; Hill, 2007). Men should not only fulfil their lives outside the home, but also share the burden of the home more equally. Men should now, it was said, develop a Self that had a 'softer side. But the criticisms were quick to follow, and it was debated whether the Swedish manhood was in crisis. The notion of this type of crisis was based on the assertion that there were more structural problems, rather than focusing on the individual's development. For example, the term 'velour dad' was coined as a criticism of a soft and compassionate manhood that had lost the ability to be a solid guide for the family and society. In this way, two different perspectives on 'crisis' seemed to collide in what could be seen as a masculine project of the 1970s. 
In this article, my aim is to analyse the 'individual crisis' as a keyword (Williams, 1976), with a culture-analytical perspective on how masculinity and emotion came to matter in the 1970s - not least for bringing about gender equality in the Swedish welfare society (cf. de Boise \& Hearn, 2017). This will also be my empirical starting point in a discussion of how 'individual crisis' became central (1) in pinpointing the way men should create a new 'Self' (cf. Rose, 1996) and (2) for new psychological knowledge to circulate in society (cf. Secord, 2004; Hansson \& Irwin, 2020). I am especially interested in the science of psychology, and how the knowledge about masculinity in this science circulated into other fields. For example, communication of this knowledge through self-help and debate books became central in the 1970s, which will be focused on in this article.

\section{Background: Liberate the Man}

This article takes a masculinity perspective on a long research tradition focusing on the cultural changes that occurred in Sweden during what is sometimes called the long 1970s (Löfgren, 1998; Ekenstam, 2007; Hill, 2007; Cronqvist \& Sturfelt, 2008; Björk, 2011; Ljunggren, 2017a; Hansson, 2018). In the chapter 'Emotions, time and change', written by the historian Ljunggren, these changes are well described and understood in relation to theories on emotions (Ljunggren, 2017b). He starts by asking a fundamental question that is significant not only for this article but for all cultural historical research on this decade in relation to Swedish society: What makes the 1970s special, and what fundamental changes occurred in Sweden during this time? The main point is that the changes related to this decade actually began in the 1960s and continued into the 1980s. Therefore, the changes cannot simply be categorized into an individual decade. Instead, the long 1970s should be methodologically studied as a variety of events that eventually led to the specific changes that are of interest when we study the 1970s. For the research presented in this article, these changes are related to an understanding of how the concept of psychological 'individual crisis' was introduced at this time, debated, and gradually became an important aspect of what can be seen as part of the formation of a modern masculinity in Sweden.

In the dissertation, 'Liberate the man' (2007), Hill reflects upon the formation of this modern masculinity. From a history of ideas perspective, she analyses how the Swedish men's movement in the mid-1970s was one of many starting points for questioning men's position in society. She looks specifically into the social movement, 'Befria mannen' ('Liberate the Man'), and how the view of masculinity became a main topic for starting a discussion about gender roles and gender differences - which became even more central in the discussion and debate of the 
1980s. Men were now to liberate and work with their Self, and in this way change not only their own identity but also the entire society's view reflecting what was seen as an outdated, hegemonic masculinity (cf. Connell \& Messerschmidt, 2005). ${ }^{3}$ But the questioning of what was defined as an old and more bourgeois masculinity-and criticizing it from the perspective of gender differences (cf. Eduards, 2002) - also simultaneously created a fear that these men, and this new form of masculinity, would not be seen as 'real men'. They were categorized as 'unmanly' and 'feminine' or, to use the label presented in the introduction, 'velour dads. Consequently, while men were to seek a Self that did not support a form of hegemonic masculinity-a masculine narrative whereby men could continue to 'ideologically [legitimate] the global subordination of women to men' (Connell \& Messerschmidt, 2005: 832) - at the same time this movement was seen as a threat to all manhood. Hill writes: 'The men's movement's statements and practices may on the one hand be considered subversive. Merely by acting differently, they showed that it was possible to exist in different ways and that masculinity was not a stable and unchangeable phenomenon. But the criticism against them and the definition of them as unmanly also gave rise to fear' (p. 9).

However, looking outside the men's movement, we can see that there was an increasing range of debate and self-help books in the 1970s that discussed the need for new roles for men (cf. Backman, 2005; Hill, 2014). These books can help us understand some of the cultural movements in the long 1970s, to go beyond the focus on criticism and fear of the men's movement and instead study the 'shaping of the private Self' (Rose, 1996), which became increasingly central at this time. Here, Ljunggren engages in an important discussion about authenticity (2017b) - which is also partially discussed in other research, although without the contextual focus on Sweden (cf. Hill, 2007; de Boise \& Hearn, 2017). The shaping of the private Self emanated from finding new, more authentic emotions that were central to a self-actualizing naturalness. This is a matter that de Boise \& Hearn (2017) consider to be an essential discussion when emotions are seen as an important part of 'improving men's emotional communication as a key to fostering greater gender equality' (p. 780). In the 1970s, men were to feel in new ways and thereby create a form of masculinity that could generate a more authentic man (Ljunggren, 2017) - which was not always easy. What were the obvious, and right, feelings to have? And what happened when it became a duty to be faithful to one's feelings-was it still authentic? These kinds of questions raised the need for help and guidance in taking care of oneself and one's emotions. Self-help and debate books can be seen as an answer to these questions. While both sought to provide answers for the reader, the self-help books focused more on introducing different psychological concepts. Both types of books could be categorized as ones that argued for societal change. 
In this article, this kind of care for oneself is regarded as part of a larger structure that can be understood from the perspective of biopower (cf. Foucault, 1978; Lemke, 2011). This is a cluster of theories that attempts to analyse how modern society governs people through a form of internal discipline; in this way, they become good citizens (cf. Frykman, 1992; Armstrong, 1995), good men. Through a form of internal 'self-care', people are expected to take care of their Self (Alftberg \& Hansson, 2012). For men, as we shall see in this article, this could mean adapting to a modern working life, participating more in family life, becoming a good father, or handling divorce in a proper manner. It could be argued that self-care changed for men in the 1970s, and that it became a main point to adapt to a society that involved a more flexible working life and active parenting, while at the same time risking divorce due to more liberal divorce laws (cf. Beck, 1992). The old concept of hegemonic masculinity, it was said in the self-help and debate books, no longer worked. My analysis is less focused on the political and critical perspectives, which Hill (2007) analyses, concentrating instead on those cultural changes that were much more modest and subtle (cf. Ehn \& Löfgren, 2010) but still changed the conditions of being a man. So, how do we capture this multifaceted subject?

\section{Method: Knowledge in Transit}

Methodologically, the analysis in this article focuses on the 'individual crisis' as a keyword. Williams develops this term, and views keywords as nodes that connect and bind together different units that convey meaning (Williams, 1976; cf. Arvidson, Ursula \& Hansson, 2013). These units can be whole stories, small sentences, metaphors, or cultural categorizations. This article discusses how masculinity is described and explained through these different units. It is these units that change when the word receives a new meaning, when it is in transit, shifting into something different. In this way, studying keywords can say something not only about how different central words (for example, 'individual crisis') are used in a historical context, but also about the ways in which these words change over time and thus how society changes (for example, regarding masculinity). Methodologically, keywords can therefore also provide an understanding of how the knowledge about 'individual crisis' and men is in transit. Here, I follow Secord's thoughts on knowledge in transit when he writes that 'we need to shift our focus and think about knowledge-making itself as a form of communicative action' (2004: 661). This theoretical viewpoint, or statement if you like, means that we also need to analyse 'every text, image, action, and object as the trace of an act of communication, with receivers, producers, and modes and conventions of transmission' (p. 661). 'Individual crisis' is such a keyword in transit, especially in 
the 1970s, and became central at this time as an understanding of people's mental well-being as well as of the transformations that occurred in the norms regarding masculinity.

One example of this change was the Swedish psychiatrist and psychoanalyst Johan Cullberg, born in 1934, introducing the term 'individual crisis' in his research. ${ }^{4}$ In this way, the word 'crisis' was related to a much broader discussion about 'individual crises' that people might have in life. In the Swedish book Crisis and Development. A Psychoanalytic and Social Psychiatric Study from 1975, the term was introduced to the general public in Sweden. This book can thus be seen as a form of knowledge-making, which in the mid-1970s created a communicative action that was part of how the keyword 'crisis' changed and began to mean something slightly different. In this article I am interested in studying books like Cullberg's, from a cultural analytical point of view, as a form of knowledge in transit. I will also return to Crisis and Development.

Therefore, my empirical goal in this article has not been to seek material that is simultaneously complete and limited, but rather to find books that (1) describe the term 'individual crisis' in different ways and (2) discuss the new roles for men in the 1970s. In this way, the analysis is inspired by the bricolage method, which brings together different sources and thus creates new stories of the phenomenon being studied (Ehn, 2011). Beckman, with the support of Lévi-Strauss, argues that bricolage is a method in which the sources are reconstructed in different ways in order not to give just one answer but rather to create a diverse understanding of the phenomenon studied (Beckman, 2009; see Lévi-Strauss, 1966). This, I want to emphasize, is essential when we study keywords in transit.

To create this bricolage, nine books have been collected, read, and analysed. This collection was done in a motley way, first using different search engines with search words like 'crises', 'individual crisis', and 'midlife crisis' (a term often used in relation to 'individual crisis'). After this, cross-references between books were used to find books that seem to have been important for all authors to refer to at the time. Based on my categorization, the collection consists of self-help books and debate books. Self-help books can be seen as those that are more pedagogical and that introduce the perspectives behind 'individual crisis'. All the books were written by Swedish authors, and they have in common that they all somehow discuss masculinity in relation to 'individual crisis'. The books were published between 1974 and 1982, most of them in the second half of the 1970s.

\section{The Concept of 'Individual Crisis' in Sweden}

I shall start by introducing the term 'individual crisis' and how it was not necessarily treated as a gender-specific issue but instead tried to encompass the 
whole human as a psychological being. At the same time, I argue throughout this article that the clash with the prevailing masculinity norms in the 1970s, previously slightly superficially defined as hegemonic masculinity (cf. Connell \& Messerschmidt, 2005), was likely stronger than that with the norms that existed for women at the same time. As we will see, in the term 'individual crisis' authenticity to one's emotions became crucial and was something that both men and women were to be aware of and regard as important for their own development and psychological well-being. But even if this vision of the sentient person was much more problematic for men, this is not discussed much in books like Cullberg's Crisis and Development (cf. Ekenstam, 2007). Instead, these contradictions are much more prominent in the debate books. Before I analyse these books, however, I will present how the term 'individual crisis' was introduced in Sweden and the reason for the use of this psychiatric term.

Cullberg and a group around him introduced the term 'individual crisis' at the end of the 1960s and the beginning of the 1970s in Sweden (cf. Hansson, 2012 \& 2013). At the time, it was mainly used in hospitals when providing help to people with milder mental problems who did not require hospitalization. The conditions described by the term could be depression after unemployment, grief at the death of a relative, or sadness after a divorce. Many of the theories on psychotherapy came from research and clinical use in the United States, having mainly developed during the 1950s based on Sigmund Freud's psychoanalysis. During the first part of the 1970s, an increasing number of books that were related, in one way or another, to the concept of 'individual crisis' were published in Sweden for the public. One of these books was Cullberg's own Crisis and Development, published in 1975. This book became highly influential in presenting the term 'individual crisis' as a method for healthcare in order to help people in these situations. It was argued that modern society had changed, and that the help to individuals that had previously been provided by families and relatives was no longer there in the same way. The individual could therefore have greater expectations on the Swedish community-read the growing welfare society-to assist in situations when the individual needed help. In this way, the book became a communicative action of knowledge-making, presenting directions for how the modern welfare society could develop.

In the book, the concept of 'individual crisis' was presented as a way to understand, and also solve, men's and women's mental problems. The crisis was not seen as something negative, but instead as an opportunity to evolve and grow as a human being. This was part of the argument that one should accept that life could be difficult, which was a central theme in many of the other books analysed in this study. In his text, Cullberg points out that one should be interested not 
only in the triggering events of the 'individual crisis' but also in the individual's psychological development. In the book, Cullberg presents a definition of what he considers to be a mental condition: 'A state of mental crisis that can be described as finding yourself in a life situation such that your previous experiences and learned modes of reaction are not sufficient for understanding and mentally coping with the current situation' (p. 12). But he also relates this to a fundamental part of how the individual grows and matures: 'The growing human being constantly tries to incorporate the novelties she encounters with her past experiences into a coherent, meaningful whole' (p. 13).

This perspective of the growing human being is related to the discussion about authentic emotions and how important they are for the individual process of finding and shaping the private Self (cf. Ljunggren, 2017b). This was even more explicit in the book 'People in crisis' by Eva Ekselius, Dag Notini, and Gunnar Öberg, published a year after Cullberg's book in 1976. In this book, the authors present 'individual crises' in a pedagogical way but at the same time are slightly more polemic than Cullberg, arguing that we acquire a false human view by learning to wear facades. Thus, they argue more strongly for the authentic feelings that people have and need to relate to. They write:

But this whole human view is false. For most people, life does not pass as a state of even happiness. Life is not calm and conflict-free. Conflicts are instead necessary for change and development. To be able to cope, it is necessary for a person who is threatened to become upset or indignant. Grief and sadness are natural reactions to difficult experiences and losses. It is therefore important to distrust the happiness ideal. (pp. 2-3)

In this way, the authors argued that it was important to take responsibility for the feelings one could have, be it grief, sadness, or various other forms of being upset. These feelings were considered important for the individual's self-care and for the necessary change and development of the individual. In this form of self-care, the individual was expected not to suppress their feelings but rather to use them as a possibility to take care of their Self (cf. Hansson, 2012). This was especially linked to the 'individual crisis' and was highlighted throughout the book: 'In this way, the crisis can be both fruitful and enriching' (p. 5) and 'The crisis is the process of creating a new pattern' (p. 5). Hence, it was argued that the individual had a responsibility to take their own feelings seriously and listen to them; at the same time, the aim of the authors of this book was to support healthcare professionals in helping people in these situations. This was argued for in the debate book, Man in Crisis: A Debate Book Based on the Suicide Issue: 'Every person, wherever they 
are in this country, should be able to look up a telephone number or an address in the telephone directory and in the social catalogue and find an experienced and knowledgeable being who can help and support them in an emergency crisis, whatever the crisis may be' (Folksam. Sociala rådet, 1976: 23). At the same time, one could argue that it was this view of the individual taking responsibility for their Self that was problematic for men; that it was not obvious to men to take their feelings seriously and regard them as a starting point for changing their own identity. But this collision between an older masculinity ideal-comprehended as part of the hegemonic masculinity (cf. Connell \& Messerschmidt, 2005)—and 'individual crisis' was not always visible in the educational books, which focus on this theory as similar for men and women. Instead, we need to look more closely at the debate books that problematized this new perspective on 'individual crisis' and masculinity, and that argued that men need to deal with the fear of relating to their feelings and their unwillingness to change.

\section{A New Manhood?}

In this part of the analysis I will focus on the books that can be categorized as debate books. One way to understand these books is to regard them as an answer to the questions that arose in relation to second-wave feminism, the second phase of the women's movement that began in the United States at the beginning of the 1960s and then spread to the rest of the Western world. This wave focused mainly on inequalities between women and men, and thus had an emancipatory role in strengthening the role of women. This became a central political discussion in Sweden, and in the early 1970s resulted in the implementation of reforms with the goal of engendering equality in society (cf. Hansson, 2018). These changes in Sweden, described here only very briefly due to the limited space of the article, also emphasized the need for men to find a new masculinity that was in line with these changes. This might include taking more responsibility in the household, being a more present father, daring to talk about one's feelings when depressed, and so on. In the book, Lifetime: About male desire and denial from 1978, the author Erik Centerwall clarifies this and relates it to societal challenge:

The man has been directly linked to working life and its patriarchal patterns. As patriarchy now takes on new forms, so does the role of men. The liberation takes place from the old system and can be experienced with some relief, you experience a development towards greater and greater personal freedom, the development goes forward, as does the production of society and the whole society: sexual liberation is also 
included, and you can venture to talk about things you would never dare say before. And the debate is radicalized and creates a series of new identities. (p. 82)

Looking at the photograph on the book cover (see Picture 1), as readers we can understand that these 'new gestures' that the man is expected to embrace can be troublesome. Examples might be identities to desire, to change not only the individual but to, in solidarity, change one's relation to women and, in the long run, change society. But it is important, Centerwall points out, that men do not deny this change and turn their backs and become silent. Instead, it was now essential for the individual to dare listen to his inner feelings and form a new masculinity, which was described as opposed to older hegemonic and patriarchal masculinity patterns. In this way, the change to a more equal society was also framed as a project for men, who should strive for other identities and let go of old patterns. In the debate books, this was perceived as an act of solidarity with women.

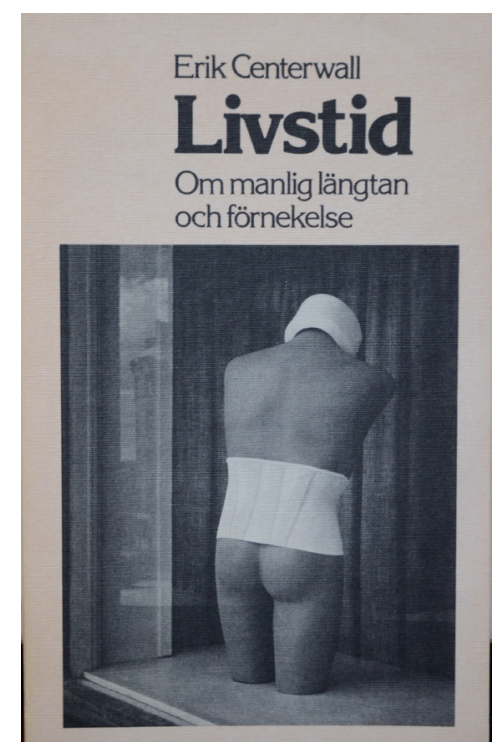

Picture 1 The picture on the front cover for the book Lifetime: About male desire and denial (Centerwall, 1978), illustrates a form of masculinity that the author wants to question. It is the torso of a man whose back is turned away from us, and who seems to be lonely. Moreover, it seems to be in a commercial context, in a shop window. What is it that the man needs to sell?

But, using Ljunggren's words, we can also speak of authenticity and of how the individual should seek a more 'personal freedom' (Ljunggren, 2017b). Consequently, it was not only women who were oppressed; men were also 
recognized as being oppressed when they did not have the possibility to seek this personal freedom. This should be seen as an empirical perspective on how 'oppression' was discussed in Sweden in the 1970s. The picture on the book cover could be interpreted in this manner, as a reminder that the man must turn around and face life. In the debate book, The right to be human from 1975, the authors Marit Paulsen, Sture Andersson, and Georg Sessler continue this argument that men are oppressed. In the book, they argue that men are oppressed when they cannot handle the new demands of society: 'The man's inability to handle his own private affairs must be an oppression of him as an independent man' (p. 102). What this book aimed to argue for was the right of men to take care of themselves emotionally, but also to take responsibility for the family and the household (cf. Ljunggren, 2917b). They were very concrete: 'It must be stressful for your self-confidence to know that you have to go dirty and hungry between the refrigerator and the washing machine. It is a completely unreasonable situation that a grown man cannot take care of his personal needs-so unreasonable that one feels ashamed to write such a thing in $1974^{\prime}$ (p. 102).

The cover of this book is progressive, aiming to emphasize one of the new roles the man needed to take on in order to be an 'independent man' (see Picture 2). The photo has obvious similarities with a much more well-known image, an advertisement by the Swedish Social Insurance Agency Försäkringskassan from 1974. The weightlifter Lennart 'Hoa-Hoa' Dahlgren, an extremely masculine but cosy kind of man, was holding a newborn; this was to market the new and world-unique parental insurance, whereby both parents had the right to take parental leave for six months. He became the dad who had big, masculine muscles and at the same time signalled that he was a man who could care for children - that this was not a contradiction. The muscular man on the cover of the book, The right to be human, also frames this kind of cultural proposition of the man as strong and masculine and simultaneously caring and soft.

But to succeed with this transformation, to become this new man, it was important for men to take care of their feelings, a discussion that can be related back to the concept of 'individual crisis', described above. This, I argue, was central in all debate books and was also linked to the discussions in self-help books. Here I will take another example from the debate book, Pictures of men: about a fragmented reality, written by Erik Centerwall and Ingrid Strömdahl (with photos by Gunnar Smoliansky) and published by the National Board of Health and Welfare in 1979. In almost poetic language, the authors argued for the importance of daring to show what you feel, to yourself and to others: 'Not showing what you feel-you can do that all your life. In the end, you also become alien to your own feelings' (p. 4). Alienation, as a Marxist concept, has also been discussed by Ljunggren as a main point in the 1970s and in relation to authenticity (Ljunggren, 


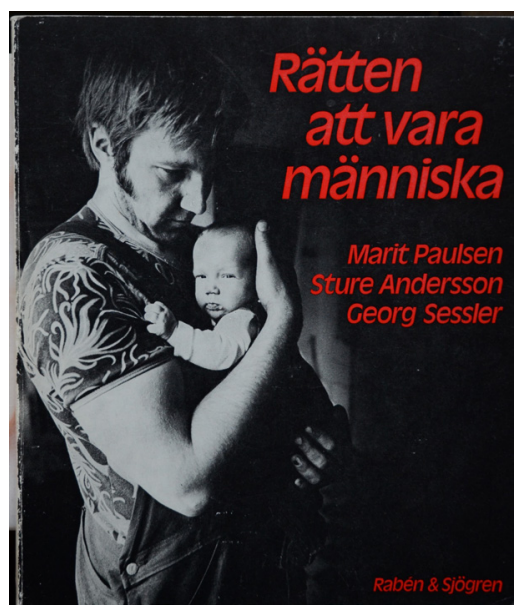

Picture 2 The black and white image on the front cover for the book The right to be human (Paulsen, Sessler \& Andersson, 1975), gives a sense of documentary photography; that we are meeting a man in an authentic situation. It is a situation signalling a modern man: the hand holding the child's fragile head and the gaze seeking the baby. Is he seeking a relationship? But it is also an image that clarifies the closeness a child creates, even with a father.

2017b). By not listening to your authentic feelings, there was a risk of creating an alienated Self. It was essential to learn to understand your authentic feelings if you wanted to change this alienating masculinity. This was also the aim of the book: 'The more I understand myself, the less I need to play a role. Nevertheless, I need that protective shell around what is shameful, insecure, or scary' (p. 4). In many ways, this way of reasoning in the debate books had many similarities to the narrative way 'individual crisis' is presented above: it was the individual's responsibility to listen to their inner feelings and take them seriously. Accordingly, one can say that the historical context during the long 1970s seems to be in line with thoughts that were first presented in relation to 'individual crisis' in the late 1960s and early 1970s.

But the similarities do not stop here. In the debate books, there is also the thought that men who are unable to show what they feel-who hide their authentic feelings-are in crisis. In the previously cited book, Lifetime: About male desire and denial, Centerwall discussed this in the following words: 'When I see other men, I also see that they are actually living in constant crisis, whereby the external role means a constant denial of other parts of the personality. It is a constant crisis that comes from an unresolved split' (p. 12). This could be defined as an 'individual crisis', but at the same time it is something more. In the debate books, this kind of formulation should also be read as a criticism of society and an assertion that all men were in some form of crisis. As discussed earlier, many of the books linked this to patriarchal patterns that seemed hard to change. Centerwall posited that 
this was a pattern of the capitalist society: 'The man is by tradition and necessity so strongly linked to production, men's society and exploitation, with all of man's myths and self-denial, that he cannot just let go and fall headlong' (p. 14). So, it seemed that the term 'crisis' in these books was focused more on the crisis that masculinity norms hindered men from changing than on the more individual crises' that the pedagogical books described. But there were certain themes in which men seemed to have 'individual crises', as their old identity did not work together with a new society. Such a theme was fatherhood.

\section{Becoming a Father}

Looking at the books, one can find a couple of themes that were categorized as problematic for men in one way or another. Many of these problems were discussed in relation to the changes that took place in society in the early 1970s and related to family formation. New divorce laws and parental benefits for both men and women changed the possibilities for how one could arrange family life (ch. Hansson, 2018). But when reading the books, it is obvious that men lagged behind and were not as inclined to change as society wished. This finding has been shown in other research focusing on how family and marriage were discussed in the 1970s (cf. Lennerhed, 1994; Wiklund, 2006; Olsson, 2011; Bergman, 2017). In my empirical foundation, I want to highlight Eva Ekselius' book, Lone father, lone mother. How the single parent solves their problems, from 1974. In this book, she describes this very delicately: 'In many respects, parental life is different from a bachelor's life. It gives a great deal that bachelor life can never give, but a parent must also renounce much of the single and childless freedom of movement and discharge' (p. 10). Two years later, Nils Uddenberg was much harsher in his criticism directed at men. In 1976, in the book, To have children: A holistic view of crisis and adaptation when you become a parent, he wrote:

Our current cultural patterns allow the man to live in much the same role after becoming a father as he did before. He can maintain his old goals and ideals. Although it is desirable from his own, the woman's, and the child's point of view that he change his lifestyle, the environment does not place the same demands on him as on the woman. (p. 26)

The purpose of the book was to provide an explanation of the crisis reactions men and women can experience when they have children. But, as the quote makes clear, this response to 'individual crisis' is different for men and women. Here, Uddenberg follows a similar argument discussed earlier: that the man did not seem capable of seeing that he needed to change; that he simply lacked the 
developing part of the 'individual crisis'. This was also debated in the book, People in crisis, by Ekselius, Notini, and Öberg in 1977, who wrote: 'Unfortunately, it is rare that the father's crisis is given enough attention' (p. 42).

A difference in reasoning compared with the debate books is that there is no unclear alienation that the individual needs to relate to; rather, Uddenberg, as well as Ekselius, Notini, and Öberg, focus more on what they see as general cultural patterns in society that need to change. The argument seems to be that it is through this change that men can receive the attention they need. The cultural patterns, the environment, 'do not place the same demands on him as on the woman', Uddenberg writes. In this way, the criticism of the man is also clarified, namely that society has changed but the man has not followed. The culture seems to be sluggish and tough.

It is in this criticism that much of the analysed literature reveals a pattern. It is the men and their masculinity norms that are the problem in changing society in the direction desired by modern Swedish society (cf. de Boise \& Hearn, 2017). The 'individual crisis' is thus a keyword that gives us an opportunity to understand this criticism, but also to understand what the solution might be. Although the changes are described as solid actions and rooted in structures that society must provide resources to meet, it is also argued that the man must understand his own feelings. He would simply need to manage his own 'individual crisis'. In 1982, Nils Uddenberg published his next book, The eroded father. A book about men and reproduction, in which this argument was even more explicit. Under the heading 'Men need a parenting crisis', he writes: 'However, in a society where both the man and the woman care for the baby when it is newborn, he needs to undergo psychological development, just as she does, during the period they are expecting their child' (p. 41). Looking at the cover photo and reading the title of the book, we can understand that this is a criticism of the lost patriarchal father role but at the same time a cry for a modern father role (see Picture 3 ). The picture shows a modern working man with a shirt and tie, but with an empty face, one that has lost its male identity perhaps.

So, while the 'individual crisis' focused on the individual man and his own responsibility to listen to the authentic feelings that could help him adapt and become a modern father, there was also this thought of the modern society that should help the individual. Thus, there is a contradiction that is interesting. The theories on 'individual crisis' can be regarded as a liberal self-fulfilment programme, but in transit from the United States to Sweden it seemed to transform into something more (cf. Secord, 2004). In Sweden, the welfare state was expanding, and the idea was that the strong society should help people with the kind of problems that people could have in their everyday life, for example men becoming fathers. 


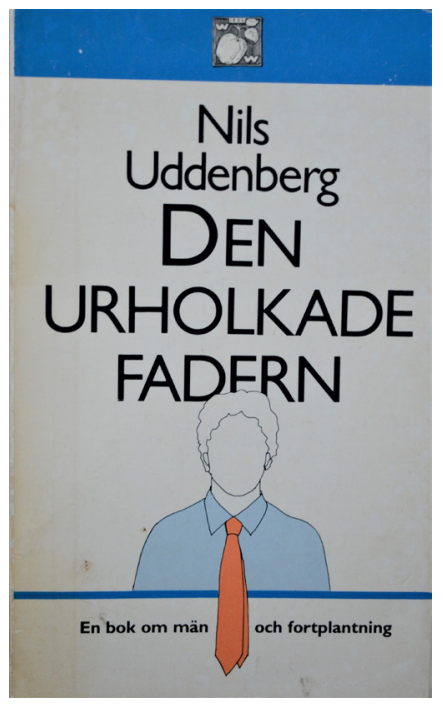

Picture 3 This is the opposite of the cover photo in Picture 2 an anonymous man, without children. The front cover for the book The eroded father. A book about men and reproduction (Uddenberg, 1982), perhaps points to the growing individualism that came to be so prevalent during this decade. In this way, it ties together 1970s ideas about the man and the development thereafter.

\section{Conclusion: Men and the Self-care of Emotions}

In this article, Williams' keyword has been used to perform a cultural analysis of how the term 'individual crisis' travelled through the long 1970s (cf. Williams 1976). It can be seen as a form of moving knowledge that slowly changed the ways men could relate to their Self. Men could now be in crisis; they could have an 'individual crisis'. But within this movement there were many other forces in society that did not want to see men as having a soft and compassionate manhood. Instead, it was said that men in Sweden were in crisis. This article aims to make a contribution to how we can understand that a man could be in crisis at the same time as there was a crisis of men.

At the end of the 1960s, 'individual crisis' was a term used by only a small group of healthcare practitioners. By the mid-1970s, however, the term had been transformed and had become a way of understanding how men in Sweden needed to change in relation to new norms. Studying the different narratives related to crisis during this decade, it is possible to analyse which masculinity ideals and norms existed at the time. Furthermore, it is a method that opens up the possibility to analyse knowledge and how it travels through history (cf. Secord, 2004).

Considering knowledge as something that is in transit, I further want to argue that new ideas concerning 'individual crises' at the end of the 1960s and the beginning of the 1970s also affected the growing picture that the Swedish man was in crisis. Above all, ideas about authentic feelings came to be a crucial matter 
for which men were to take responsibility. It was by way of these feelings that the man could go through an 'individual crisis', and in this way grow to be a better human being. This was directly linked to a form of self-care which made it clear that it was the individual's responsibility to find their own Self. When it came to fatherhood, this was obvious. Society had changed and had given both men and woman opportunities; now, it was up to the men to adapt to these changes. It was essential that the man did not alienate himself and hide behind old patriarchal structures.

In the modern Swedish welfare state, men and women had thus been given a new form of freedom (cf. Beck, 1992). Now they had the opportunity to shape family life in such a way that the woman did not end up doing all the housework and solely taking care of the children. They also, through the 'individual crisis', had an instrument for succeeding with this transformation from a society based on a hegemonic masculinity to an equal society. Central to this change, I would argue, was a form of 'shaping of the private Self' (Rose, 1996) in relation to this new and modern society. But the institutions in the welfare society were also prepared to help: healthcare centres were started that used methods from the theories on 'individual crisis' (cf. Hansson, 2012 \& 2018). A new masculinity could emerge and be shaped.

But with what we know now, we can say that this did not actually happen. The change to an equal society did not proceed as quickly as society seemed to wish in the 1970s. Instead, it seems as though the theories on 'individual crisis' strengthened men's self-realization project, which then expanded in the 1980s (cf. Björk, 2011). It is as if the project that was launched in the 1970s, with a focus on the man taking responsibility for his own improvement, ran aground. It was as if this specific kind of biopower, to use Foucault's terminology (1978), did not really relate to the actual culture of the 1970s. Instead, the criticism found in the term 'velour dad', for example, clarifies that there were other forces in society that wanted a different development. But that is another story.

Kristofer Hansson is a lecturer at the Department of Social Work, Malmö University and holds an Associate Professorship in Ethnology. Email: kristofer. hansson@mau.se

\section{Notes}

1 All quotes and book titles have been translated from Swedish into English by the author.

2 In Swedish different terms are used. For example: 'den individuella krisen', 'den psykiska krisen', 'mognadskris', 'livskris' (cf. Hansson, 2012, 2013). All these terms have different meanings but are united in their focus on the person's individual development. In this article I have chosen the term 'individual crisis'. 


\section{Culture Unbound}

Journal of Current Cultural Research

3 In this article, 'hegemonic masculinity' is used mainly as an emic concept, focusing on how it was used in the 1970s. Connell and Messerschmidt give a short origin of the concept and how it became central in the 1970s in relation to the Gramscian term 'hegemony' and 'the related debates over the role of men in transforming patriarchy' (Connell \& Messerschmidt, 2005: 831). In the mid-1980s, it was formulated as an etic concept in the academic field of masculinity studies - "Hegemonic masculinity was understood as the pattern of practice (i.e., things done, not just a set of role expectations or an identity) that allowed men's dominance over women to continue" (p. 832).

4 See, for example, Cullberg 1971 \& 1975. I present his research more in-depth in Hansson 2012 \& 2013.

\section{References}

Alftberg, Åsa \& Hansson, Kristofer (2012): "Introduction: Self-care Translated into Practice," Culture Unbound. Journal of Current Cultural Research, 4, 415-424.

Armstrong, David (1995): "The Rise of Surveillance Medicine," Sociology of Health \& Illness, 17:3, 393-404.

Arvidson, Mats, Geisler, Ursula \& Hansson, Kristofer (2013). "Inledning: Kulturvetenskapliga perspektiv på kris," Arvidson, Mats, Geisler, Ursula \& Hansson, Kristofer (ed): Kris och kultur: Kulturvetenskapliga perspektiv på kunskap, estetik och historia. Lund: Sekel Bokförlag, 9-27.

Backman, Stina (2005): Den sjuke mannen: Populärkulturella gestaltningar av manlig ohälsa. Linköping: Carlsson Bokförlag.

Beck, Ulrich (1992): Risk Society: Towards a New Modernity. London: Sage.

Beckman, Anita (2009): Väntan: Etnografiskt kollage kring ett mellanrum. Göteborg: Mara.

Bergman, Helena (2017): "Feminism, kärlek och ilska: Känsloregler och känslopolitik i 1970-talets Sverige," Bergman, Helena, Florin, Christina \& Ljunggren, Jens (ed): Känslornas revolution: Kärlek, ilska och lycka på 1970-talet. Stockholm: Appell Förlag.

Björk, Maria (2011): Problemet utan namn?: Neuroser, stress och kön i Sverige från 1950 till 1980. Uppsala: Uppsala universitet.

de Boise, Sam \& Hearn, Jeff (2017): "Are men getting more emotional? Critical sociological perspectives on men, masculinities and emotions," The Sociological Review, 65: 4, 779-796.

Centerwall, Erik (1978): Livstid: Om manlig längtan och förnekelse. Stockholm: Liber Förlag.

Centerwall, Erik, Smoliansky, Gunnar \& Strömdahl, Ingrid (1979): Mansbilder: Om en splittrad verklighet. Stockholm: Liber Förlag.

Connell, R. W. \& Messerschmidt, James W. (2005): Hegemonic Masculinity: Rethinking the Concept, Gender \& Society, 19:6, 829-859.

Cullberg, Johan (1971): "Det psykiska traumat: Om kristeori och krispsykoterapi," Sfph:s monografiserie, No 1.

Cullberg, Johan (1975): Kris och utveckling: En psykoanalytisk och socialpsykiatrisk studie. Stockholm: Natur och Kultur.

Cronqvist, Marie \& Sturfelt, Lina (2008): “En träff med tidsandan," Cronqvist, Marie, Sturfelt, Lina \& Wiklund, Martin (red): 1973: en träff med tidsandan. Lund: Nordic Academic Press.

Eduards, Maud (2002): Förbjuden handling: Om kvinnors organisering och feministisk teori. Malmö: Liber ekonomi. 


\section{Culture Unbound}

Journal of Current Cultural Research

Ehn, Billy (2011): “Att fånga det undflyende: Kulturanalytiskt bricolage som metod," Sellerberg, Ann-Mari \& Fangen, Katrine (red): Många olika metoder. Lund: Studentlitteratur.

Ehn, Billy \& Löfgren, Orvar (2010): The Secret World of Doing Nothing. Berkeley: University of California Press.

Ekenstam, Claes (2007): “Den kännande människan,” Ekenstam, Claes \& Johansson, Per Magnus (red): Människobilder: Tio idéhistoriska studier. Hedemora: Gidlunds Förlag.

Ekselius, Eva (1974): Ensam far, ensam mor: Hur den ensamstående föräldern löser sina problem. Stockholm: Bonnier.

Ekselius, Eva, Notini, Dag \& Öberg, Gunnar (1977): Människor i kris. Stockholm: Esselte Studium.

Folksam. Sociala rådet (1976): Människa i kris: En debattbok med utgångspunkt från självmordsfrågan. Stockholm: Folksam.

Foucault, Michel (1978): Histoire de la sexualité. 1, La volonté de savoir. Paris: Gallimard.

Frykman, Jonas (1992): "In Motion: Body and Modernity in Sweden Between the World Wars," Ethnologia Scandinavica, 22, 36-51.

Hansson, Kristofer (2012): "Crisis and Caring for Inner Selves: Psychiatric Crisis as a Social Classification in Sweden in the 1970s," Culture Unbound. Journal of Current Cultural Research, 4, 499-512.

Hansson, Kristofer (2013): "’De svåra kriserna i lifvet kringgår man inte': Psykiska kriser och synen på den utvecklande människan," Arvidson, Mats, Geisler, Ursula \& Hansson, Kristofer (ed): Kris och kultur: Kulturvetenskapliga perspektiv på kunskap, estetik och historia. Lund: Sekel Bokförlag, 113-128.

Hansson, Kristofer (2018): "Vårt liv, min kris: Skilsmässans kulturella förändringar under 1970-talet," Salomonsson, Karin (ed): Mitt och ditt: Etnologiska perspektiv på ägandets kulturella betydelse. Lund: Lund Studies in Arts and Cultural Sciences, 115-135.

Hansson, Kristofer \& Irwin, Rachel (2020). “Movement of knowledge: Introducing medical humanities perspectives on medicine, science, and experience," Hansson, Kristofer \& Irwin, Rachel (eds): Movement of knowledge: Medical humanities perspectives on medicine, science, and experience. Lund: Nordic Academic Press, 9-26.

Hill, Helena (2007): Befria mannen!: Idéer om förtryck, frigörelse och förändring hos en svensk mansrörelse under 1970- och tidigt 1980-tal. Umeå: Umeå universitet.

Hill, Helena (2014): "Drömmen om en ny man: maskulinitet och nationell identitet i talet om 'nya svenska män'," Burman, Anders \& Lennerhed, Lena (eds): Tillsammans: politik, filosofi och estetik på 1960- och 1970-talen. Stockholm: Atlas Akademi.

Lemke, Thomas (2011): Biopolitics: An advanced introduction. New York: New York University Press.

Lennerhed, Lena (1994): Frihet att njuta: Sexualdebatten i Sverige på 1960-talet. Stockholm: Stockholms Universitet.

Lévi-Strauss, Claude (1966): The Savage Mind. Chicago: University of Chicago Press.

Ljunggren, Jens (2017a): "Inledning: Känslor, tid och förändring," Bergman, Helena, Florin, Christina \& Ljunggren, Jens (red): Känslornas revolution: Kärlek, ilska och lycka på 1970-talet. Stockholm: Appell Förlag.

Ljunggren, Jens (2017b): "Kampen om vreden: 1960- och 70-talens emotionella utmaning av den svenska socialdemokratin," Bergman, Helena, Florin, Christina \& Ljunggren, Jens (red): Känslornas revolution: Kärlek, ilska och lycka på 1970-talet. Stockholm: Appell Förlag.

Löfgren, Orvar (1988): Hej, det är frän försäkringskassan!: Informaliseringen av Sverige. Stockholm: Natur och kultur. 


\section{Culture Unbound}

Journal of Current Cultural Research

Paulsen, Marit, Sessler, Georg \& Andersson, Sture (1975): Rätten att vara människa. Stockholm: Rabén \& Sjögren.

Olsson, Jenny-Leontine (2011): Kön i förändring: Den svenska könsrollsforskningen 1959-1979. Stockholm: Stockholms universitet.

Rose, Nikolas (1996): Inventing our Selves: Psychology, Power, and Personhood. New York: Cambridge University Press.

Secord, James A. (2004): “Knowledge in Transit," Isis, 94(4), 654-672.

Uddenberg, Nils (1976): Att få barn: En helhetssyn på kris och anpassning när man blir förälder. Stockholm: Natur och kultur.

Uddenberg, Nils (1982): Den urholkade fadern: En bok om män och fortplantning. Stockholm: Wahlström \& Widstrand.

Wiklund, Martin (2006): I det modernas landskap: Historisk orientering och kritiska berättelser om det moderna Sverige mellan 1960 och 1990. Lund: Lunds universitet.

Williams, Raymond (1976): Keywords: A Vocabulary of Culture and Society. London: Fontana. 